\section{Antiproliferative activity of Eremanthus crotonoides extracts and centratherin demonstrated in brain tumor cell lines}

\author{
Jonathas F. R. Lobo, ${ }^{1}$ Elaine S. Castro, ${ }^{2}$ Dayana R. Gouvea, ${ }^{3}$ \\ Caio P. Fernandes, ${ }^{4}$ Fernanda B. de Almeida, ${ }^{4}$ Lídia M. F. de \\ Amorim, ${ }^{2}$ Patrícia Burth, ${ }^{2}$ Leandro Rocha, ${ }^{4}$ Marcelo G. Santos, ${ }^{5}$ \\ Lidilhone Harmerski, ${ }^{6}$ Norberto P. Lopes, ${ }^{3}$ Angelo C. Pinto ${ }^{1}$
}

\author{
${ }^{1}$ Instituto de Química, Universidade Federal do Rio de Janeiro, Brazil, \\ ${ }^{2}$ Departamento de Biologia Celular e Molecular, Instituto de Biologia, Universidade \\ Federal Fluminense, Brazil, \\ ${ }^{3}$ Núcleo de Pesquisa em Produtos Naturais e Sintéticos, Faculdade de Ciências \\ Farmacêuticas de Ribeirão Preto, Departamento de Física e Química, Universidade \\ de São Paulo, Brazil, \\ ${ }^{4}$ Laboratório de Tecnologia de Produtos Naturais, Faculdade de Farmácia, \\ Universidade Federal Fluminense, Brazil, \\ ${ }^{5}$ Faculdade de Formação de Professores de São Gonçalo, Universidade do Estado \\ do Rio de Janeiro, Brazil, \\ ${ }^{6}$ Núcleo de Pesquisas em Produtos Naturais, Centro de Ciências da Saúde, \\ Universidade Federal do Rio de Janeiro, Brazil.
}

\begin{abstract}
The genus Eremanthus is recognized by the predominance of sesquiterpene lactones from the furanoheliangolide type, a class of substances extensively tested against cancer cell lines. Thus, the species E. crotonoides (DC.) Sch. Bip., Asteraceae, obtained on "restinga" vegetation was evaluated against U251 and U87-MG glioma cell lines using the MTT colorimetric assay. Dichloromethane fraction was cytotoxic to both glioblastoma multiforme cell lines. We then conducted UPLC-PDA-ESI-MS/MS analysis of the dichloromethane fraction, which allowed the identification of the sesquiterpene lactones centratherin and goyazensolide. The isolation of centratherin was performed using chromatographic techniques and the identification of this substance was confirmed according to NMR data. Cytotoxic activity of centratherin alone was also evaluated against both U251 and U87-MG cells, which showed IC50 values comparable with those obtained for the commercial anticancer drug doxorubicin. All the tested samples showed cytotoxic activity against glioblastoma multiforme cells which suggests that E. crotonoides extracts may be important sources of antiproliferative substances and that the centratherin may serve as prototype for developing new antiglioblastoma drugs.
\end{abstract}

Revista Brasileira de Farmacognosia Brazilian Journal of Pharmacognosy 22(6): 1295-1300, Nov./Dec. 2012

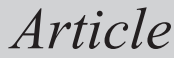

Received 18 Aug 2012

Accepted 1 Oct 2012

Available online 16 Nov 2012

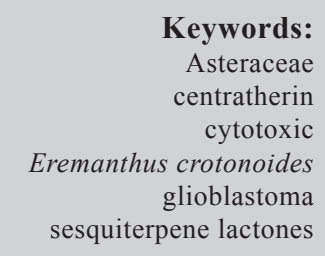

ISSN 0102-695X http://dx.doi.org/10.1590/S0102695X2012005000131

\section{Introduction}

Plants from the Asteraceae family are commonly used in Brazilian folk medicine, health care and as foodstuffs. The subtribe Lychnophorinae (Vernonieae, Asteraceae) is endemic to Brazil and many of their species are used in anti-inflammatory preparations. However, other biological activities have been described such as antimicrobial and cytotoxic properties, especially for the Lychnophora and Eremanthus species (Santos et al., 2009; Keles et al., 2010). The phytochemical profile of this subtribe indicates a predominance of sesquiterpene lactones and flavonoids. In current medical research, extracts obtained from species rich in sesquiterpene lactones have been extensively tested against cancer cell lines, allowing for the discovery of promising anticancer drugs. These include thapsigargin, parthenolide and derivatives of these compounds that are currently in clinical trials for the treatment of cancer (Ghantous et al., 2010).

The genus Eremanthus Less comprises 27 species of trees and shrubs that are normally found in "cerrado" (Brazilian savanna), but E. crotonoides is an exception that can also be found in "restinga" (sandy 
coastal plains) (Santos et al., 2009). Studies carried out for species from this genus indicated the predominance of sesquiterpene lactones from the furanoheliangolide class (goyazensolide and eremantholide types) as their characteristic constituents (Vichnewski \& Gilbert, 1972; Raffauf et al., 1975; Bohlmann et al., 1980, 1981, 1982; Vichnewski et al., 1989; Rüngeler et al., 1998; Sacilotto et al., 2002; Sakamoto et al., 2005).

Therefore, the aim of the present work was to evaluate antiproliferative effects of extracts and sesquiterpene lactone from Eremanthus crotonoides against two brain tumor cell lines.

\section{Materials and Methods}

\section{Plant material}

The leaves of Eremanthus crotonoides (DC.) Sch. Bip., Asteraceae, used in this work were collected in Restinga de Jurubatiba National Park, Rio de Janeiro, Brazil, and identified by the botanist Dr. Marcelo Guerra Santos, Universidade do Estado do Rio de Janeiro, Brazil. A voucher specimen (M. Guerra Santos 2150) has been deposited at the Herbarium of the Faculdade de Formação de Professores, Universidade Estadual do Rio de Janeiro, Brazil.

\section{Preparation of extracts}

The air-dried and powdered leaves $(1.8 \mathrm{~kg})$ of E. crotonoides were extracted with ethanol $(98 \%)$ at room temperature for seven days with daily agitation. After evaporation of the ethanol under reduced pressure, the ethanolic extract (ECE, $145.3 \mathrm{~g}$ ) was suspended in water and then sequentially extracted with $n$-hexane, dichloromethane, ethyl acetate and $n$-butanol to give $n$-hexane (ECH, $58.3 \mathrm{~g}$ ), dichloromethane (ECD, 36.5 $\mathrm{g}$ ), ethyl acetate (ECEA, $12.9 \mathrm{~g}$ ), and $n$-butanol (ECB, $27.6 \mathrm{~g})$ fractions, respectively. All solvents were purchased from Tedia (USA).

\section{Sample preparation for UPLC analysis}

ECD fraction was analyzed by chromatography using UPLC-PDA-ESI-MS/MS to identify the presence of sesquiterpene lactones. An aliquot of $2.5 \mathrm{mg}$ of ECD was weighed in a glass vial and then was added to $2.5 \mathrm{ml}$ of a solution of $\mathrm{MeOH}-\mathrm{H}_{2} \mathrm{O}$ (4:6). The final solution (1 mg/ $\mathrm{mL}$ ) was filtered on a $13 \mathrm{~mm}$ GHP, $0.22 \mu \mathrm{m}$ microporous membrane and then submitted to UPLC analysis $(5.00 \mu \mathrm{L})$ by autosampler.

\section{UPLC method condition}

The analysis was performed using a Waters
Acquity UPLC system equipped with a waters Acquity UPLC $\lambda$ PDA detector and managed by MassLynx software version 4.1 (SCN 714). The analytical chromatography column used to separate the components of the sample was an Acquity $1.7 \mu \mathrm{m}(2.1 \times 50 \mathrm{~mm}) \mathrm{BEH}$ (Ethylene Bridged Hybrid) $\mathrm{C} 18$, equipped with an equivalent material pre-column. The gradient program employing a flow rate of $0.3 \mathrm{~mL} / \mathrm{min}$ was as follows: solvent A: water; solvent B: methanol; elution profile: 0-10 $\mathrm{min}, 10-100 \%$ B (linear gradient), 10-12 min, 100\% B (isocratic), 12$12.5 \mathrm{~min}, 100-10 \%$ B (linear gradient), $12.5-15 \mathrm{~min}, 10 \%$ $\mathrm{B}$ (isocratic). The PDA detector was monitored to record between $200 \mathrm{~nm}$ and $400 \mathrm{~nm}$ and the column temperature was established at $30^{\circ} \mathrm{C}$.

\section{Electrospray ionization (ESI) MS/MS conditions}

The MS/MS system utilized was a Waters Acquity TQD tandem quadrupole mass spectrometer integrated with a UPLC system via an ESI ion source. The analyses were performed in the positive mode $(\mathrm{ES}+)$. The conditions used were as follows: capillary voltage, $3.49 \mathrm{kV}$; cone voltage, $28.08 \mathrm{~V}$; source temperature, $148{ }^{\circ} \mathrm{C}$; desolvation temperature, $250{ }^{\circ} \mathrm{C}$; cone gas flow, $2.0 \mathrm{l} / \mathrm{h}$; desolvation gas flow (N2), 497 $\mathrm{L} / \mathrm{h}$; collision gas flow, $0.10 \mathrm{~mL} / \mathrm{min}$; collision gas, argon; nebulizer gas, high-purity nitrogen. The value of $10 \mathrm{eV}$ was the best energy collision, because it permits the display of the maximum intensity of product ions.

\section{Fractionation and isolation}

ECD fraction $(6.0 \mathrm{~g})$ was submitted to a rapid silica-gel (70-230 mesh) column clean-up under vacuum conditions by using the solvents $n$-hexane $(1,0 \mathrm{~L}), n$-hexane $(0,5 \mathrm{~L})$, dichloromethane $(1,0 \mathrm{~L})$, dichloromethane-ethyl acetate $(6: 4)(0,5 \mathrm{~L})$, dichloromethane-ethyl acetate $(4: 6)$ $(0,5 \mathrm{~L})$, ethyl acetate $(1,0 \mathrm{~L})$ and ethanol $(1,0 \mathrm{~L})$ (Tedia, USA), to give fractions FR1, FR2, FR3, FR4, FR5, FR6 and FR7, respectively. These six fractions were analyzed by TLC GF254 (Macherey-Nagel) using $n$-hexane-ethyl acetate-methanol (5:5:1) as eluent system. Subsequently, a visual inspection was performed under short-wave UV $(254 \mathrm{~nm})$. FR4 (250.0 mg) was submitted to reversed-phase (C18) vacuum-liquid chromatography eluted with ethanolwater (4:6), ethanol-water (6:4), ethanol and ethyl acetate to obtain the sub fractions SUB-1, SUB-2, SUB-3, and SUB-4 respectively. The SUB-1 (138.5 mg) was purified by preparative TLC eluted with $n$-hexane-ethyl acetatemethanol (5:5:1) yielding the majority compound EC1 (118.7 mg). ${ }^{1} \mathrm{H}$ and ${ }^{13} \mathrm{C}$ NMR analysis of this substance were carried out in Bruker DPX-200 MHz spectrometer. Deuterated chloroform (Cambridge Isotope Laboratories, USA) was used for solubilization and TMS peak was used as internal standard. 


\section{Cytotoxicity assay}

The human glioma cancer cell lines U87-MG and U251 were acquired from ATCC (Washington, DC, USA). These cells were maintained in DMEM (GIBCO, SP, Brazil) supplemented with $10 \%$ fetal bovine serum inactivated at $56{ }^{\circ} \mathrm{C}, 100 \mathrm{U} / \mathrm{mL}$ penicillin, and $100 \mu \mathrm{g} /$ $\mathrm{mL}$ streptomycin (Gibco, SP, Brazil) at $37^{\circ} \mathrm{C}$ in a humid atmosphere containing 5\% $\mathrm{CO}_{2}$. Briefly, Cells $\left(5 \times 10^{4} /\right.$ well) were plated in 96-well plates and on the next day incubated with EEC, ECD, or centratherin at different concentrations $(0.005-160 \mu \mathrm{g} / \mathrm{mL})$ over a period of 24 h. Doxorubicin (Bergamo Ltda, SP, Brazil) was used as a positive control, while DMSO (Merck, RJ, Brazil) as a negative control. After incubation, cytotoxicity was assessed by MTT (Sigma Aldrich, St. Louis, USA) reduction (Mosman, 1983) and quantified with a spectrophotometer (mQuant, Biotek Instruments) at $545 \mathrm{~nm}$. The results of 3 experiments in triplicate were used to calculate IC50 by nonlinear regression using GraphPad prism 5.0 Software.

\section{Morphological analysis}

The morphology of U87-MG and U251 cell lines treated with $10 \mu \mathrm{g} / \mathrm{mL}$ of ECE, ECD and centratherin or DMSO $0.01 \%$ for $24 \mathrm{~h}$ was directly observed and photographed with an inverted light microscope (Bel Photonic INV100-FL). All photos were taken at 200x magnification.

\section{Results and Discussion}

Regarding literature data, it can be observed that sequential partition of ethanolic extract from Eremanthus species with solvents of increasing polarity allow the achievement of a sesquiterpene enriched dichloromethane fraction (Sakamoto et al., 2005, 2010). Thus, chromatographic fingerprint analysis of the dichloromethane fraction (ECD) from leaves of Eremanthus crotonoides (DC.) Sch. Bip., Asteraceae, was carried out by UPLC-PDA-MS and MS/MS. In the total ion chromatogram obtained by UPLC-PDA-

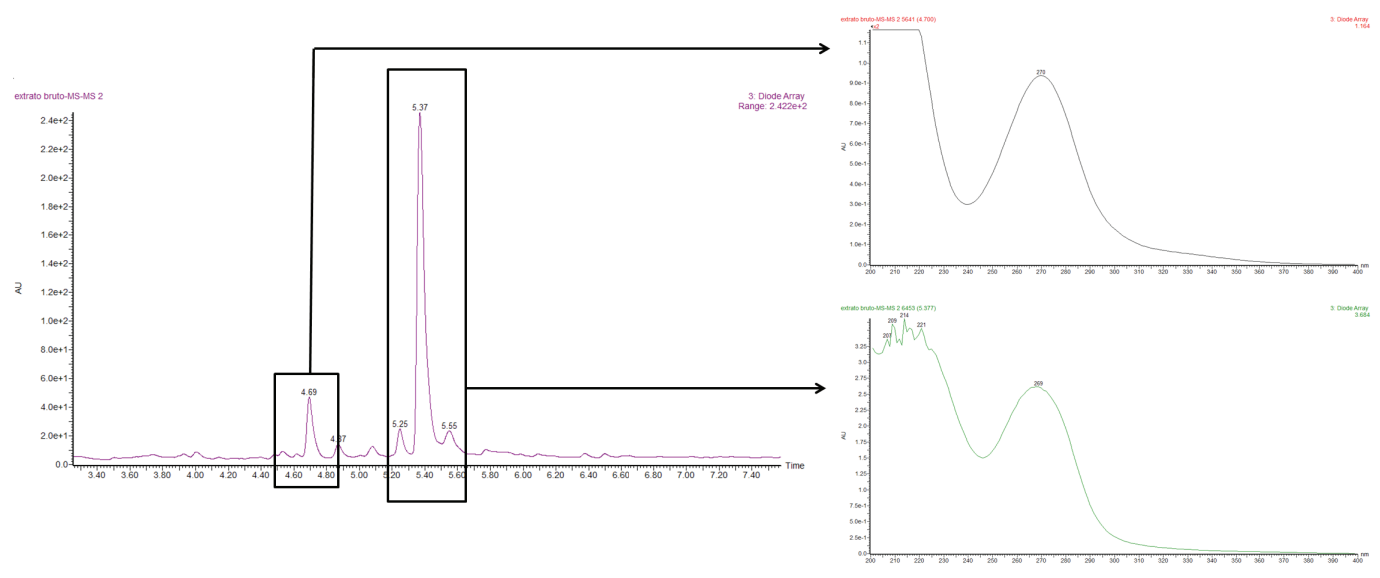

A

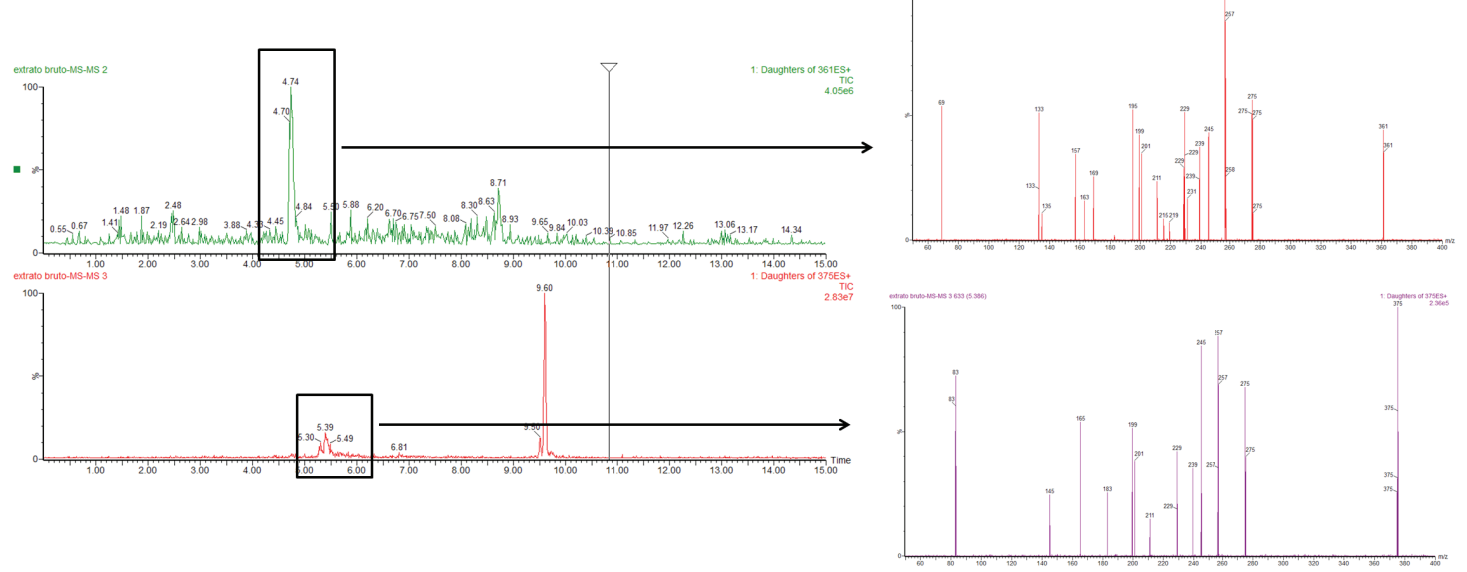

Figure 1. Chromatograms obtained from UPLC-PDA-ESI-MS/MS analysis in the dichloromethane fraction (ECD) obtained from leaves of Eremanthus crotonoides. A. PDA chromatogram and the UV spectra at 4.7 and 5.4 min peaks, and B. MS/MS chromatogram and the product ion spectrum in the positive ion mode, obtained by MS/MS analysis, from the ions at $m / z 361$ and 375 , respectively. 
MS/MS analysis (Figure 1A,B), peaks at 4.7 and 5.4 min, exhibited precursor ions at $\mathrm{m} / \mathrm{z} 361$ and 375, respectively, as well as typical sesquiterpene lactone UV spectra $\left(\lambda_{\text {max }}: 270 \mathrm{~nm}\right.$ ) (Moraes et al., 2009). The product ion spectrum in the positive mode, obtained by MS/MS analysis, from precursor ion at $\mathrm{m} / \mathrm{z} 361$ $[\mathrm{M}+\mathrm{H}]^{+}$showed initially a loss of 86 units leading to the formation of an ion at $m / z 275$, which have been associated with the corresponding esters in $\mathrm{C}-8$, being eliminated as carboxylic acid $\left[\mathrm{C}_{3} \mathrm{H}_{5} \mathrm{CO}_{2} \mathrm{H}\right]$. After this, 18 and 28 units were lost from the fragment ion at $\mathrm{m} / \mathrm{z} 275\left[\mathrm{M}+\mathrm{H}-\mathrm{C}_{3} \mathrm{H}_{5} \mathrm{CO}_{2} \mathrm{H}\right]$ to generate ions at $\mathrm{m} / \mathrm{z}$ $257\left[\mathrm{M}+\mathrm{H}-\mathrm{C}_{3} \mathrm{H}_{5} \mathrm{CO}_{2} \mathrm{H}-\mathrm{H}_{2} \mathrm{O}\right]+$ and $m / z 247[\mathrm{M}+\mathrm{H}-$ $\mathrm{C}_{3} \mathrm{H}_{5} \mathrm{CO}_{2} \mathrm{H}-\mathrm{CO}$, which are formed by the loss of $\mathrm{H}_{2} \mathrm{O}$ and $\mathrm{CO}$ respectively. The ion at $\mathrm{m} / \mathrm{z} 257$ (presented as the base peak) lost $\mathrm{CO}$ (28 units) to produce a signal at $\mathrm{m} / z 229$, followed by the loss of $\mathrm{H}_{2} \mathrm{O}$ (18 units) to generate an ion at $\mathrm{m} / \mathrm{z} 211$. The ion at $\mathrm{m} / \mathrm{z} 201$ was generated by the loss of CO (28 units) from the ion at $m / z$ 257. The MS spectra obtained from precursor ion at $\mathrm{m} / \mathrm{z} 361$ was compared with literature data (Crotti et al., 2005) and therefore allowed the identification of goyazensolide (1). Subsequently, the MS/MS product ion spectrum from the precursor ion at $\mathrm{m} / z 375[\mathrm{M}+\mathrm{H}]$ showed the loss of 100 units leading to the formation of a product ion at $m / z 275$. This process is characterized by the loss of esters in C-8 (eliminated as carboxylic acid). Afterward, the ion at $\mathrm{m} / z 275\left[\mathrm{M}+\mathrm{H}-\mathrm{C}_{4} \mathrm{H}_{7} \mathrm{CO}_{2} \mathrm{H}\right]$ lost $\mathrm{H}_{2} \mathrm{O}$ (18 units) and $\mathrm{CO}$ (28 units) leading the formation of ions at $\mathrm{m} / \mathrm{z} 257$ and at $\mathrm{m} / \mathrm{z} 247$. The fragment ion at $\mathrm{m} / z 257$ (base peak) lost 28 units (CO) to produce a signal at $m / z 229$, followed by the loss of 18 units $\left(\mathrm{H}_{2} \mathrm{O}\right)$ leading to the formation of an ion at $\mathrm{m} / \mathrm{z} 211$. There is a signal at $\mathrm{m} / \mathrm{z} 239$, which was generated by the loss of 2 molecules of water (36 units) from the ion at $m / z 275$. The MS spectra obtain from precursor ion at $\mathrm{m} / \mathrm{z} 375$ was compared with literature data (Crotti et al., 2005) allowing the identification of centratherin (2).

Aditional column fractionation and preparative thin-layer chromatography allowed the obtainment of an amorphous white powder $(118.7 \mathrm{mg})$. The isolated compound was confirmed as centratherin (2-butenoic acid, 2-methyl-, $(3 \mathrm{a} R, 4 S, 6 R, 10 Z, 11 \mathrm{a} R)-2,3,3 \mathrm{a}, 4,5,6,7,11 \mathrm{a}-$ octahydro-10-(hydroxymethyl)-6-methyl-3-methylene2,7-dioxo-6,9 epoxycyclodeca [b]furan-4-yl ester, (2Z)-) by comparison of its ${ }^{1} \mathrm{H}$ and ${ }^{13} \mathrm{C}$ NMR spectra with those published in the literature (Ohno et al., 1979; Vichnewski et al., 1990). In addition, PDA chromatogram indicated that centratherin (Rt $5.4 \mathrm{~min}$ ) (Figure 1A) presented the major relative percentual on ECD.<smiles>[R]C1C[C@@]2(C)OC(=O)C=C2C(CO)=C[C@H]2OC(=O)C(=C)[C@@H]12</smiles><smiles>[R]C(=O)C(C)=O</smiles><smiles>CC(=O)/C(C)=C\C=[13C]</smiles>

The first phytochemical investigation of leaves from E. crotonoides, which were collected in "Cerrado" (Brazilian savanna), described three new furanoheliangolides, in addition to six known furanoheliangolides (Bohlmann et al., 1982). However, to our knowledge, the sesquiterpene lactones from the furanoheliangolide class centratherin (2) and goyazensolide (1) had not been previously identified in this species. It is interesting for an ecological overview that $E$. crotonoides was collected in "restinga" habitat. Since secondary metabolites represent a chemical interface between plants and surrounding environment (Gobbo-Neto et al., 2007), this aspect must be considered regarding to the difference in chemical composition of the present study, characterized by the high content of centratherin, when compared to its previous phytochemical characterization.

ECE and ECD fractions obtained from leaves of E. crotonoides were cytotoxic to both tested glioblastoma multiforme cell lines (U87-MG and U251) (Table 1). Glioblastoma multiforme is the most aggressive form of glioma and, despite recent research advances into glioma genesis and treatment, it continues to be a lethal disease with a dismal prognosis (Adamson et al., 2009). Previous studies described antiproliferative effects of centratherin against small cell lung cancer (NCI-H187) (Vongvanich et al., 2006) and goyasenzolide against seven different tumor cell lines, especially leukemic cell lines (Santos et al., 2004). As part of ongoing studies for discovering substances with potential antiproliferative action against glioblastoma cells, the isolated sesquiterpene lactone centratherin was also tested. It showed an IC50 of 3.57 and 8.06 $\mu \mathrm{g} / \mathrm{mL}$ (Table 1) against U87-MG and U251 cell lines, respectively.

Table 1. IC50 values for antitumor effects obtained by treatment with ECE, ECD, and centratherin against glioma cell lines (U251 and U87-MG). Doxorubicin was used as positive control.

\begin{tabular}{ccccc}
\hline \multirow{2}{*}{ Cell line } & \multicolumn{4}{c}{ IC50 $(\mu \mathrm{g} / \mathrm{mL})$} \\
\cline { 2 - 5 } & ECE & ECD & Centratherin & Doxorubicin \\
\hline U251 & $61.06 \pm(44.48-83.82)$ & $19.56 \pm(15.67-24.42)$ & $8.06 \pm(7.00-9.22)$ & $10.43 \pm(6.35-17.13)$ \\
U87 & $46.14 \pm(32.72-65.07)$ & $16.25 \pm(6.78-30.97)$ & $3.57 \pm(2.39-5.33)$ & $3.85 \pm(0.89-16.63)$ \\
\hline
\end{tabular}


Furanoheliangolides often exhibit antiinflammatory, trypanocidal, cytotoxic, and genotoxic activities (Grael et al., 2000; Sakamoto et al., 2003; Santos et al., 2004; Vasconcelos et al., 2007;). The furanoheliangolides possess two functionalities in the form of an $\alpha$-methylene- $\gamma$-lactone and an $\alpha, \beta, \gamma, \delta$ unsaturated carbonyl group (Rüngeler et al., 1999) that can react through a stereospecific Michael addition with biological nucleophiles (mainly with the thiol groups of cysteine residues present in proteins) forming stable adducts (Ghantous et al., 2010).

Morphological analysis indicated that cells treated with ECE, ECD and centratherin showed cytotoxicity effects, like rounded shape and decreased number caused by cell death. Centratherin was more effective against U87 cells than to U251 cells (Figure 2 ), corroborating results obtained through IC50 values. This difference would be due to different genetic backgrounds of cell lines such as TP53 status. TP53 codes the p53 protein, an important apoptosis regulator. Mutations in TP53 were related to chemoresistence (Bossi \& Sacchi, 2007). Considering TP53 status, U87 cell line is TP53 wild type and U251 is mutant (Chen et al., 1995). The IC50 values obtained for the centratherin was comparable to those obtained for the commercial anticancer drug doxorubicin (Table 1).

\section{Conclusion}

The present study demonstrated the antiproliferative activity of phytochemicals derived from E. crotonoides. The ethanolic extract obtained from leaves, and the dichloromethane fraction that originated from this extract, as well as the furanoheliangolide centratherin were shown to be active against glioblastoma multiforme cells (U87-MG and U251). Therefore, this substance may be useful as prototype of anticancer substances, suggesting the great potential of this species as source of bioactive substances.

\section{Acknowledgment}

This study was supported by Coordenação de Aperfeiçoamento de Pessoal de Nível Superior, Fundação de Amparo à Pesquisa do Estado do Rio de Janeiro, Fundação de Amparo a Pesquisa do Estado de São Paulo, Programa de Pós-graduação em Química da Universidade Federal do Rio de Janeiro and Programa de Pós-graduação em Ciências Farmacêuticas da Faculdade de Ciências Farmacêuticas da Universidade de São Paulo, Ribeirão Preto.

\section{References}

Adamson C, Kanu OO, Mehta AI, Di C, Lin N, Mattox AK, Bigner DD 2009. Glioblastoma Multiforme: A review of where we have been and where we are going. Expert Opin Inv Drug 18: 1061-1083.

Bohlmann F, Zdero C, King RM, Robinson H 1980. Sesquiterpene lactones from Eremanthus species. Phytochemistry 19: 2663-2668

Bohlmann F, Gupta RK, Jakupovic J, Robinson H, King RM 1981. Three germacranolides and other constituents from Eremanthus species. Phytochemistry 20: 1609-1612.

Bohlmann F, Singh P, Zdero C, Ruhe A, King RM, Robinson H 1982. Furanoheliangolides from two Eremanthus

U87
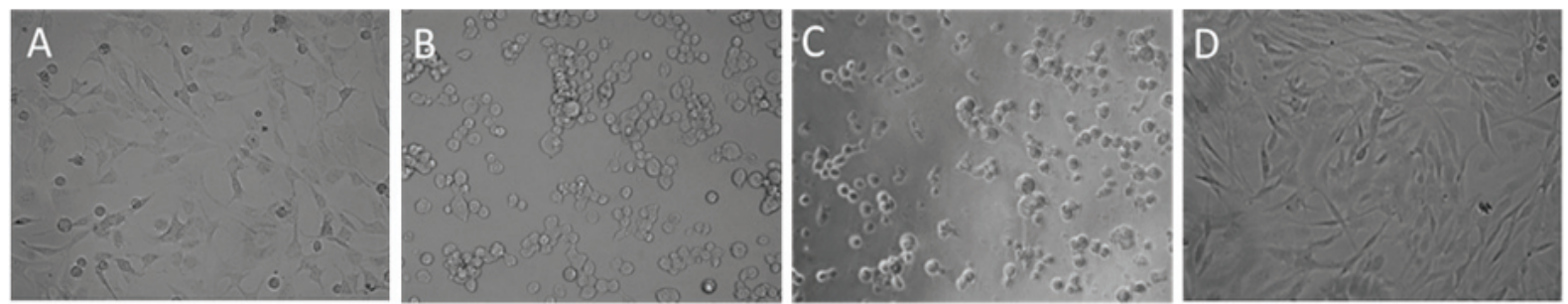

U251
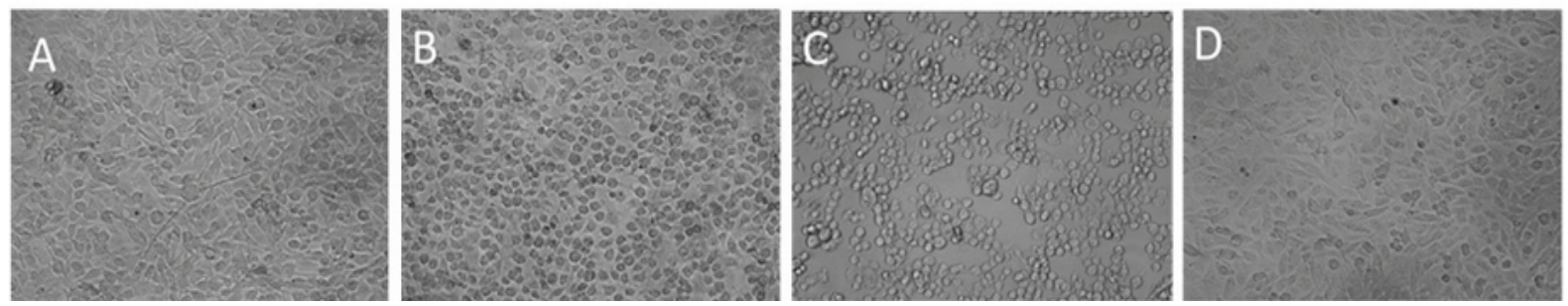

Figure 2. Morphological analysis of U87-MG and U251 cell lines after $24 \mathrm{~h}$ treatment. Cells treated with A. ECE (10 $\mu \mathrm{g} / \mathrm{mL})$; B. ECD $(10 \mu \mathrm{g} / \mathrm{mL})$; and C. centratherin $(10 \mu \mathrm{g} / \mathrm{mL})$ showed cytotoxicity effects, like rounded shape and decreased number, when compared with negative control treated with $0.01 \%$ DMSO (D). At $10 \mu \mathrm{g} / \mathrm{mL}$ concentration ECE and ECD had lower cytotoxic effect than centratherin. 
species and from Chresta sphaerocephala. Phytochemistry 21: 1669-1673.

Bossi G, Sacchi A. 2007 Restoration of wild-type p53 function in human cancer: relevance for tumor therapy. Head Neck 29: 272-284.

Chen P, Iavarone A, Fick J, Edwards M, Prados M, Israel MA 1995. Constitutional p53 mutations associated with brain tumors in young adults. Cancer Genet Cytogen 82: 106-115.

Crotti AEM, Lopes JLC, Lopes NP 2005. Triple quadrupole tandem mass spectrometry of sesquiterpene lactones: a study of goyazensolide and its congeners. J Mass Spectrom 40: 1030-1034.

Ghantous A, Muhtasib HG, Vuorela H, Saliba NA, Darwiche $\mathrm{N}$ 2010. What made sesquiterpene lactones reach cancer clinical trials. Drug Discov Today 15: 668678.

Gobbo-Neto L, Lopes NP 2007. Plantas medicinais: Fatores de influência no conteúdo de metabólitos secundários. Quim Nova 30: 374-381.

Grael CFF, Vichnewski W, de Souza GEP, Lopes JLC, Albuquerque S, Cunha WR 2000. A study of the trypanocidal and analgesic properties from Lychnophora granmongolense (Duarte) Semir \& Leitão Filho. Phytother Res 14: 203-206.

Keles LC, de Melo NI, Aguiar GP, Wakabayashi KAL, de Carvalho CE, Cunha WR, Crotti AEM, Lopes JLC, Lopes NP 2010. Lychnophorinae (Asteraceae): a survey of its chemical constituents and biological activities. Quím Nova 33: 2245-2260.

Moraes SL, Gregório LE; Tomaz JC, Lopes NP 2009. Rapid screening and identification of polar constituents from Brazilian arnica Lychnophora sp. by LC-UV/DADESI-MS and LC-UV/DAD-ESI-MS/MS analysis. Chromatographia 69: 157-165.

Mossman T 1983. Rapid colorimetric assay for cellular growth and survival: application to proliferation and cytotoxicity assay. J Immunol Methods 65: 55-63.

Ohno N, McCormick S, Mabry TJ 1979. Centratherin, a new germacranolide from Centratherum punctatum. Phytochemistry 18: 681-682.

Raffauf RF, Huang PKC, Le Quesne PW, Levery SB, Brennan TF 1975. Eremantholide A, a novel tumor-inhibiting compound from Eremanthus elaeagnus (Compositae). J Am Chem Soc 97: 6884-6886.

Rüngeler P, LyB G, Castro V, Mora G, Pahl HL, Merfort I 1998. Study of three sesquiterpene lactones from Tithonia diversifolia on their anti-inflammatory activity using the transcription factor NF-kappa B and enzymes of the arachidonic acid pathway as targets. Planta Med 64: 588-593.

Rüngeler P, Castro V, Mora G, Gören N, Vichnewiski W, Pahl HL, Merfort I, Schmidt T 1999. Inhibition of transcription factor NF- $\kappa \mathrm{B}$ by sesquiterpene lactones: a proposed molecular mechanism of action. Bioorgan
Med Chem 7: 2343-2352.

Sacilotto ACBC, Sartori FT, Vichnewski W 2002. Chemical constituents of Eremanthus veadeiroensis (Asteraceae). Biochem Syst Ecol 30: 897-900.

Sakamoto HT, Flausino D, Castellano EE, Stark CBW, Gates PJ, Lopes NP 2003. Sesquiterpenes lactones from Lychnophora ericoides. J Nat Prod 66: 693-695.

Sakamoto HT, Gobbo-Neto L, Cavalheiro AJ, Lopes NP, Lopes JLC 2005. Quantitative HPLC analysis of sesquiterpene lactones and determination of chemotypes in Eremanthus seidelii MacLeish \& Schumacher (Asteraceae). J Braz Chem Soc 16: 1396-1401.

Sakamoto HT, Laudares EP, Crotti AEM, Lopes NP, Vichnewski W, Lopes JLC, Heleno VCG 2010. Sesquiterpenes lactones and flavonoids from Eremanthus argenteus. Nat Prod Comm 5: 681-684.

Santos PA, Amarante MFC, Pereira AMS, Bertoni BW, França SC, Pessoa C, Moraes MO, Costa-Lotufo LV, Pereira MRP, Lopes NP 2004. Production of an antiproliferative furanoheliangolide by Lychnophora ericoides cell culture. Chem Pharm Bull 52: 1433-1435.

Santos MG, Fevereiro PCA, Reis GL, Barcelos JI 2009. Recursos vegetais da restinga de Carapebus, Rio de Janeiro, Brasil. Rev Biol Neotropical 6: 35-54.

Vasconcelos MC, Rosa RM, Machado MS, Villela IV, Crotti AEM, Lopes JLC, Pessoa C, Moraes MO, Lopes NP, Costa- Lotufo LV, Saffi J, Henriques JAP 2007. Genotoxicity of 15-deoxygoyazensolide in bacteria and yeast. Mutat Res 631: 16-25.

Vongvanich N, Kittakopp P, Charoenchai P, Intamas P, Sriklung K, Thebtaranonth Y 2006. Antiplasmodial, antimycobacterial and cytotoxic principles from Camchaya calcarea. Planta Med 72: 1427-1430.

Vichnewski W, Gilbert B 1972. Schistosomicidal sesquiterpene lactone from Eremanthus eleagnus. Phytochemistry 11: 2563-2566.

Vichnewski W, Takahashi AM, Nasi AMT, Gonçalves DCRG, Dias DA, Lopes JNC, Goedken VL, Gutiérrez AB, Herz W 1989. Sesquiterpene lactones and other constituents from Eremanthus seidelii, E. goyazensis and Vanillosmopsis erythropappa. Phytochemistry 28: 1441-1451.

Vichnewski W, Semir J, Leitão Filho HF, Nakashima C, Lunardello MA, Gutierrez AB, Herz W 1990. Centratherin and lychnopholide from a new Proteopsis species. Rev Latinoamer Quim 21: 28-29.

\section{*Correspondence}

Jonathas Felipe Revoredo Lobo

Instituto de Química, Universidade Federal do Rio de Janeiro

Av. Athos da Silveira Ramos, 149, Bloco A, 21941-909 Rio de Janeiro-RJ, Brazil

jfrl@ufrj.br

Tel: 552125627139 